\title{
Flood risk from groundwater: examples from a Chalk catchment in southern England
}

\author{
A.G. Hughes ${ }^{1}$, T. Vounaki ${ }^{1}$, D.W. Peach ${ }^{1}$, A.M. Ireson ${ }^{2}$, C.R. Jackson ${ }^{1}$, A.P. Butler ${ }^{2}$, J.P. Bloomfield ${ }^{3}$, \\ J. Finch ${ }^{4}$ and H.S. Wheater ${ }^{2}$ \\ 1 British Geological Survey, Keyworth, Nottinghamshire, UK \\ 2 Department of Civil and Environmental Engineering, Imperial College London, London, UK \\ 3 British Geological Survey, Wallingford, Oxfordshire, UK \\ 4 Centre for Ecology and Hydrology, Wallingford, Oxfordshire, UK
}

Correspondence

A.G. Hughes, British Geological Survey,

Keyworth, Nottinghamshire, UK

Email: aghug@bgs.ac.uk

DOI:10.1111/j.1753-318X.2011.01095.x

Key words

\begin{abstract}
Groundwater flooding has moved up the policy-makers' agenda as a result of the United Kingdom experiencing extensive groundwater flooding in winter 2000/ 2001. However, there is a lack of appropriate methods and data to support groundwater flood risk assessment. The implications for flood risk assessment of groundwater flooding are outlined using a study of the Chalk aquifer underlying the Pang and Lambourn catchments in Berkshire, UK. Groundwater flooding in the Chalk results from the water table reaching the land surface and producing long-duration surface flows (weeks to months), causing significant disruption to transport infrastructure and households. By analyzing existing data with a farmers' survey, it was found that groundwater flooding consists of a combination of intermittent stream discharge and anomalous springflow. This work shows that there is a significant challenge involved in drawing together data and understanding of groundwater flooding, which includes vital local knowledge, reasonable risk assessment procedures and deterministic modelling.
\end{abstract}

\section{Introduction}

Groundwater flooding is poorly understood, often confused with surface water flooding, and has not been widely recognised as a problem, either in the United Kingdom or internationally. The UK Government's Department for the Environment and Rural Affairs (Defra, 2004) defined groundwater flooding as: 'flooding caused when water levels in the ground rise up above the natural surface, it will often occur when accumulated rainfall over a long period of weeks or months is significantly above normal. Groundwater flooding is most likely to occur in low-lying areas underlain by permeable strata.' However, this is a simplification and does not include groundwater interaction with underground structures such as cellars and basements, and tunnels. Examples of the latter include those used for transport purposes, such as the London Underground network.

It is suggested that the following provides a more complete description. Groundwater flooding occurs due to water table rise. This is characterised by one or more of the following:

Type 1 - Extreme high intensity and/or long duration rainfall,
Type 2 - Groundwater flow in alluvial deposits by-passing river channel flood defences,

Type 3 - Cessation of groundwater abstraction for Public Water Supply or mine dewatering, e.g. London Basin and other urban areas, and

Type 4 - Underground structures creating barriers to groundwater flow.

Groundwater flooding can result in surface water ponding, intermittent stream flow or the anomalous activation of springs, as well as flooding of cellars, basements and other subsurface infrastructure, and damage to foundations. Unlike overbank fluvial flooding, groundwater floods tend to be long-lasting, typically of the order of weeks or months.

Examples in the United Kingdom of the second type of flooding include the flood events in south Oxford in 1997 (Macdonald et al., 2007, 2008a); and Pilmuir in Scotland in 1997 (MacDonald et al., 2008a, b). However, while all of the above mechanisms can result in significant flooding, it is the intense or long duration rainfall that is currently believed to be the most important source of UK groundwater flood risk (Jacobs, 2004), and is the main focus of this paper.

\begin{tabular}{|c|c|c|c|c|c|}
\hline & $\mathbf{J} \mathbf{F} \mathbf{M}$ & 1095 & Dispatch: 30.3 .11 & Journal: JFRM & CE: Deepika \\
\hline & Journal Name & Manuscript No. & Author Received: & No. of pages: 13 & PE: Thanuja/ananth \\
\hline
\end{tabular}


Groundwater flooding of this type has a long history in the United Kingdom and as defined above has been recognised within communities for a number of decades. For example, there is documentary evidence of groundwater flooding in the 1930s (McMahon, 2000), and, in areas where communities were aware of the phenomenon, house building practices were adapted to accommodate this (e.g. Morris et al., 2007). However, only in recent years has it been considered an important hazard by government agencies (e.g. Defra, 2004; Jacobs, 2004; Pitt, 2008), an importance prompted by several significant flood events. In the 1990s groundwater flooding came into sharp focus with the flooding of the city of Chichester in winter 1993/1994 (Taylor, 1994), which resulted in significant disruption to the transport network, closing a major trunk road (the A27), and flooding homes and businesses. Concerns were reinforced by extensive flooding of Chalk catchments in SE England in the Autumn/Winter of 2000/2001. Near Henley, Berkshire, floods generated during the winter of 2000/2001 affected the basement and ground floors of houses until June, when remedial work was undertaken (Robinson et al., 2001; other examples of the flooding of homes, including cellars and basements are Oxford in 1997, Macdonald et al., 2007). Significant disruption was caused by closing roads (e.g. the A338 in Berkshire 2000/2001; Robinson et al., 2001) and railways (e.g. London-Brighton line in November 2000; Binnie Black and Veatch, 2001). The cost and disruption caused by groundwater flooding, while not as much nationally as fluvial or marine flooding, can still be significant. For example, the estimated cost of the relatively localised 2000 Brighton groundwater flooding was $£ 800000$, excluding the cost of the railway closure (Binnie Black and Veatch, 2001).

Flooding in the Pang and Lambourn catchments in Berkshire during the winter of 2000/2001 is the main focus of this paper, and is discussed in detail below. The 2000/2001 flood was paralleled in Chalk catchments in north-west France. In the Somme catchment, large areas were flooded for several months by groundwater. This was studied as part of the EU FLOOD1 project (Adams et al., 2008), which included the Brighton area. Various efforts to model the flood have been made (e.g. Pinault et al., 2005; Korkmaz et al., 2009) and recently Habets et al. (2010) published a comparison of four models to reproduce flood conditions in 2000/2001. This comparison showed that the models all overestimated the heads during and after flooding. This was attributed to an overly simplistic representation of the flow processes in the deep unsaturated zone. These studies show that the flooding in the Somme during the winter of 2000/ 2001 was characterised by an increase in the quantity of the overflow rather than by a spreading of the flooded areas.

Outside the United Kingdom and north-west France, there have been a number of groundwater events recorded in Europe and the Americas. The south Galway area of southern Ireland saw extensive flooding in the late 1980s and early/mid 1990s (Peach et al., 1997; Johnston and Peach, 1998; Lees et al., 1998). This was due to the overtopping of turloughs, which are lakes fed or drained by karst groundwater systems. Groundwater flooding has also been observed in the permeable sediments in the Danube flood plain. An example of groundwater flooding circumventing flood defences has been reported in Hungary (Vekerdy and Meijerink, 1998). In the United States, groundwater flooding has been recognised by the United States Geological Survey (USGS) as occurring in glacial deposits in Washington state during the winters of 1993/1994 (Visocky, 1995) and 1996/1997 (USGS, 2000), where flooded depressions resulted in road closures. Groundwater flooding in the winter of 1993/1994 resulted in the production of 100-year return period groundwater flood risk maps (Visocky, 1995). An attempt was also made to undertake groundwater flood risk mapping in southern France (Najib et al., 2008). This work assessed groundwater flooding in karst systems using estimates of flood return periods based on groundwater hydrographs. Marechal et al. (2008), using an empirical transfer function modelling approach, proposed that thresholds of cumulative 25-day rainfall could be used to predict the occurrence of groundwater flooding in karst systems.

\section{UK policy context}

Before the Making Space for Water initiative, Defra commissioned a study to determine the extent of groundwater flooding (Jacobs, 2004). This study concluded that the Chalk aquifers of south and east England demonstrated the most important manifestation of groundwater flooding in England. This study developed predictive Groundwater Emergence Maps based on the proximity of groundwater levels to the ground surface in a winter hydrologically similar to $2000 / 2001$. This study was followed by a specific report on the Chalk aquifers (Jacobs, 2006).

The UK flood events of summer 2007 (Marsh and Hannaford, 2007) and their impacts on infrastructure resulted in the British government commissioning a review (Pitt, 2008). The Pitt review examined all aspects of surface flooding, and significantly, recommended that the Environment Agency of England and Wales (EA) should take a national responsibility for all flood risk, including groundwater flooding (Pitt, 2008). Following this recommendation, the EA published an assessment of flood risk for England and Wales (Environment Agency, 2009). Anomalous groundwater flows and levels are recognised as a cause of flooding, but no specific recommendations are made to incorporate this understanding into flood risk management. However, the EA commissioned a project in 2009 to develop tools to evaluate groundwater flood risk. Through the Flood 


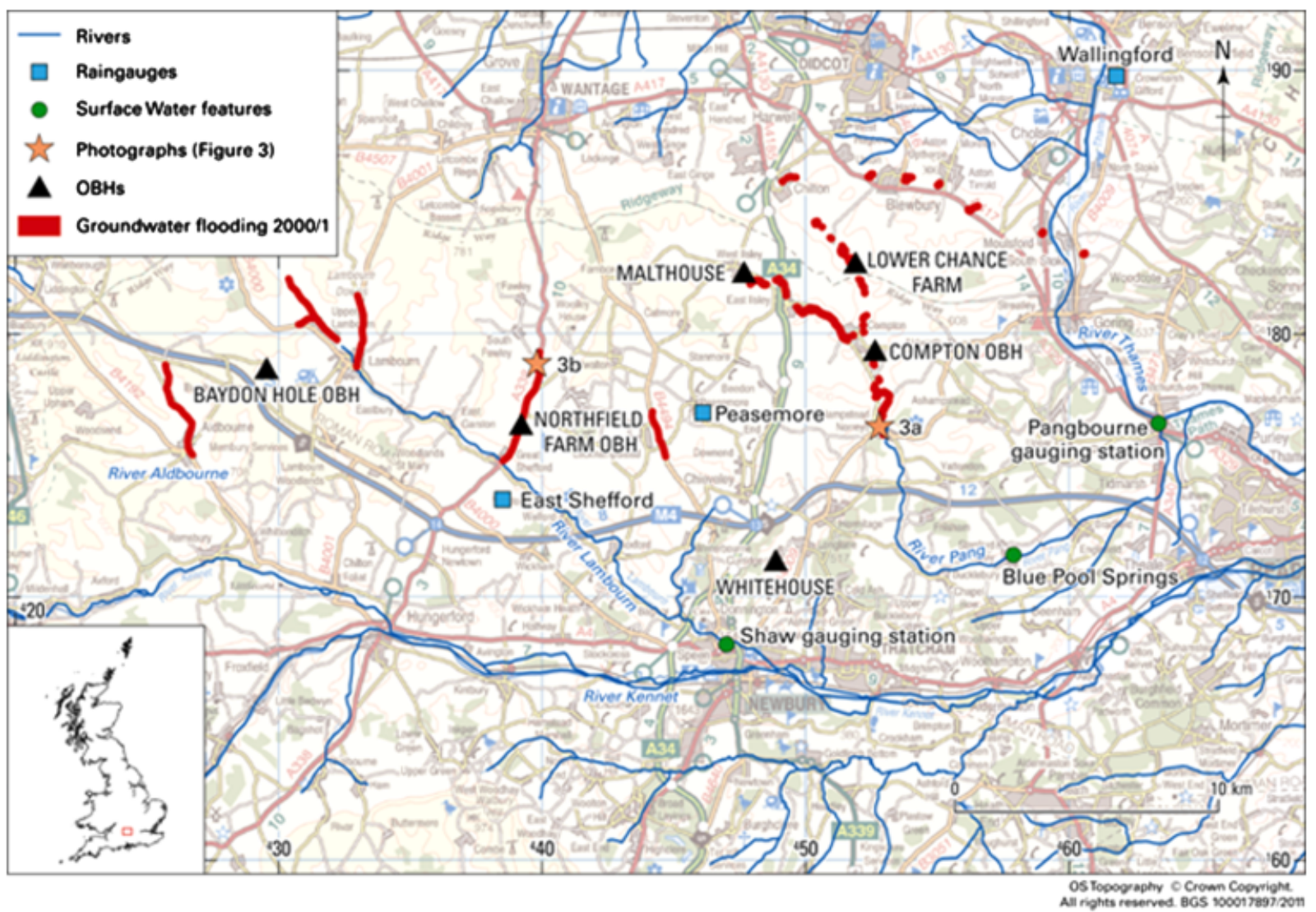

Figure 1 Main features in the Pang and Lambourn catchments.

and Water Management Act 2010, Local Authorities (LAs) now have the responsibility for groundwater flooding as it is perceived as a local issue. LAs have to keep a register of incidents as well as develop a local flood risk strategy.

The EU floods directive (2007/60/EC), which promotes the consideration of groundwater flooding, has recently come into force. This directive promotes the use of a riskbased framework for all types of flooding, and adds further pressure on the regulators to understand the hazards and risks associated with groundwater flooding. The EU floods directive, which is enshrined in the Flood Risk Regulations 2009 , stipulates that groundwater flood risk maps be produced by 2013. Possible solutions have been proposed such as Cobby et al. (2009), who suggest that the Groundwater Emergence Map work developed by Morris et al. (2007) be used to provide preliminary flood risk assessments to fulfil this requirement. National groundwater flood susceptibility maps have been produced by the BGS (Jackson, 2004; McKenzie et al., 2007) for clear water flooding, alluvial groundwater flooding and anomalous spring flow.

Therefore, the policy agenda in the United Kingdom and the EU aims to address groundwater flooding, with a commitment to groundwater flood risk assessment and groundwater flood forecasting. However, there remain a number of outstanding technical challenges that are still to be overcome to achieve these goals. Not least among these is a lack of data and physical understanding of past groundwater flood events. Hence this paper demonstrates the importance of taking groundwater into account when considering total flood risk, using historical flooding of the catchments of the River Pang and Lambourn, Berkshire, as an example.

\section{Study area}

The neighbouring Pang and Lambourn catchments are located to the west of Reading in Berkshire (Figure 1). The River Pang is a tributary of the River Thames and the River Lambourn is a tributary of the River Kennet, which in turn flows into the Thames. Land-use is predominantly rural for both catchments, the majority being grassland, with some forested areas. Rainfall varies with topography, with annual averages of $692 \mathrm{~mm}$ for the Pang catchment, $731 \mathrm{~mm}$ for the Lambourn catchment, and a maximum of $743 \mathrm{~mm}$ associated with the high ground the north and west of the catchments for the period 1968 to 1997 (Wheater et al., 2007). The catchments predominantly overlie the Chalk aquifer. Despite the importance of the Chalk as a major UK 


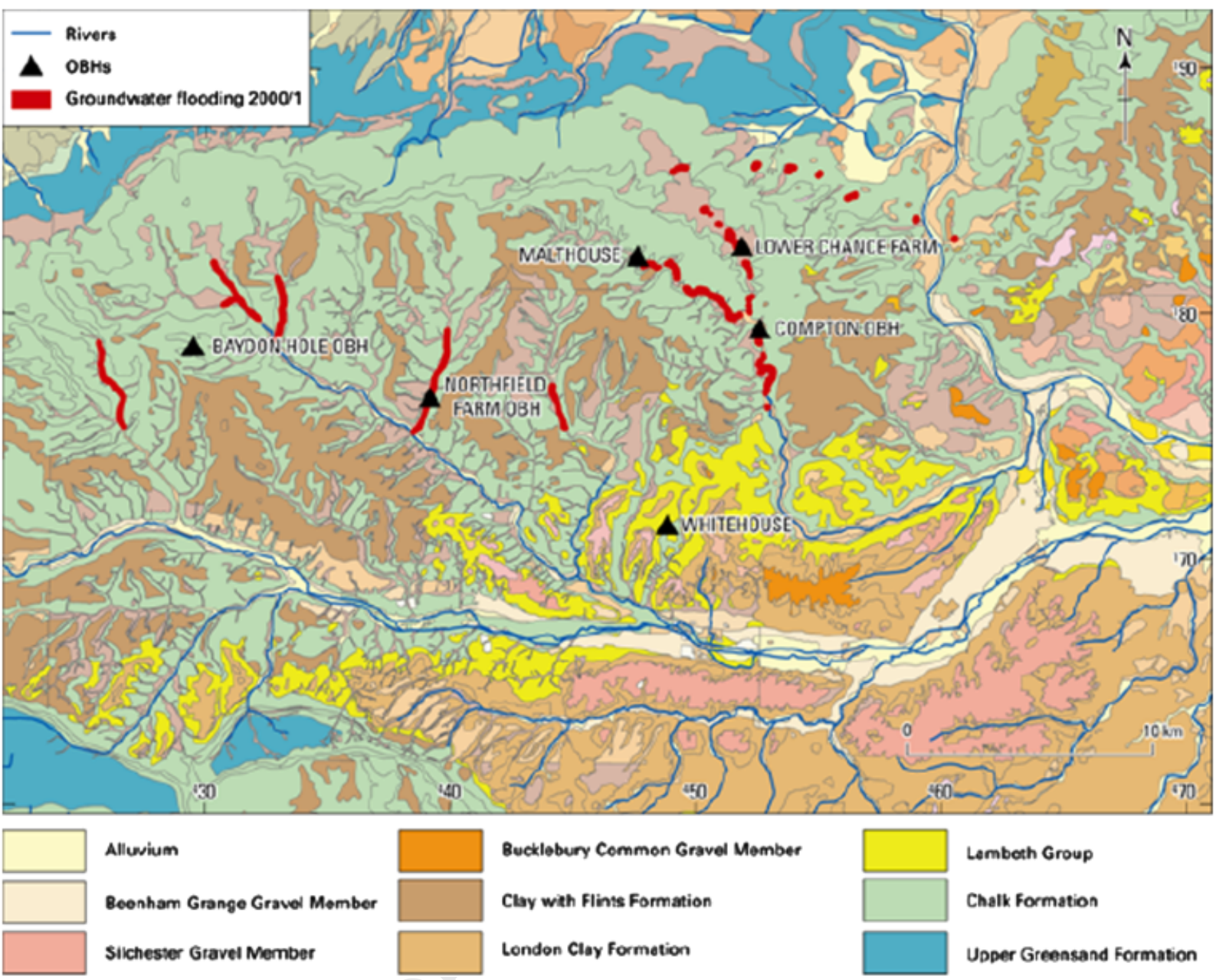

Figure 2 Geology underlying the Pang and Lambourn catchments.

aquifer, knowledge of the subsurface movement of groundwater under extreme conditions of drought and flood is poor. Groundwater flows are complex; catchments vary seasonally and are ill-defined, karst features are locally important, and groundwater-fed streams demonstrate considerable seasonality in their flow regimes.

\section{Hydrogeology}

A comprehensive summary of the current conceptual understanding of the hydrogeology of the Pang and Lambourn catchments is found in Wheater et al. (2007). These catchments have been extensively studied for a number of decades (e.g. Owen and Robinson, 1978) and recently formed part of a UK national research programme, Lowland Catchment Research (LOCAR), and were extensively instrumented and studied (see, e.g. Wheater et al., 2006). The Chalk is the major aquifer within the region and serves as a collector and distributor of recharge from rainfall, which can be transmitted either to the two tributary river systems or as groundwater flow towards the River Thames. The Chalk is overlain by Palaeogene age deposits, which include the Lambeth Group and Bagshot Beds (Figure 2) which are variably permeable. The London Clay Formation, which outcrops in the south-east of the region, is relatively impermeable and acts as an aquiclude. This restricts groundwater recharge to the Palaeogene deposits and the Chalk aquifer beneath but promotes surface run-off onto the Lambeth Group and Chalk to the north, which can then infiltrate to the groundwater table. Recharge from the base of the soil zone is spatially and temporally variable depending on a number of factors such as rainfall, evaporation, land-use, plant and soil type. Rainfall is spatially variable depending on weather systems as well as orographic effects. Recharge processes through the deep Chalk unsaturated zone are complex and nonlinear, comprising a combination of relatively slow, highly attenuated transmission of infiltrating rainfall through the Chalk matrix, and very rapid 
preferential recharge of high intensity rainfall through the fracture network (Ireson et al., 2009a, b, 2010). Superficial deposits, of Quaternary age, including alluvial deposits, glacial sand and gravels and river terrace deposits occur in the river valleys and can behave either as linear aquifers (Wheater et al., 2007), allowing surface water and groundwater to interact freely, or provide poorly permeable barriers to flow.

Saturated groundwater flow in the Chalk occurs predominantly through fractures and it is thought that in this region most groundwater flow occurs in the zone of water table fluctuation and the upper $50 \mathrm{~m}$ or so of the saturated zone (Robinson, 1976; Wheater et al., 2007). Groundwater flow is focussed in valleys due to the enhanced weathering and fracturing associated with these topographic features (Allen et al., 1997; MacDonald et al., 1998). This enhanced weathering leads to spatially variable hydraulic properties with transmissivity being an order of magnitude higher in the river valleys than in the interfluves. Groundwater flow directions are controlled by base levels provided by the major river valleys of the Thames and the Kennet, but are also influenced by abstraction within the London Basin to the south-east and scarp slope springs to the north and north-west of the region. This simple flow regime is complicated by karstic flows exemplified by the Blue Pool springs at Stanford Dingley, flow rates to which have been measured at several kilometres per day (Banks et al., 1995; Maurice et al., 2006). These and other karstic features are associated with the lower parts of the catchments whereas groundwater flooding is associated with anomalous flow in the upper regions of the catchments.

The Chalk aquifer has a major, often dominant influence on the river systems that it underlies. For example, a typical Chalk stream has a seasonal, baseflow-dominated hydrograph, reflecting the water table dynamics of the aquifer which it drains (winter recharge and a progressive water table decline through summer and autumn). The baseflow index in the River Pang is $86 \%$ for flow at the Pangbourn gauging station and is $97 \%$ for the River Lambourn at Shaw (Griffiths et al., 2006; see Figure 1). There is limited surface or near-surface run-off, unless it is generated over relatively impermeable deposits overlying the Chalk, and hence the stormflow component of streamflow response may represent as little as $2 \%$ of the incident rainfall, appearing as noise superimposed on the seasonal hydrograph. The streamflow source migrates seasonally, moving up the catchment in winter and retreating during summer; under drought conditions (or due to over-abstraction), flow may cease over significant lengths of channel. This intermittent nature of these Chalk streams, called bourne behaviour, is enhanced during extreme events. In droughts the streams become shorter and in groundwater flooding events they become longer.

\section{River-aquifer interactions}

To understand groundwater flooding properly, the bourne behaviour of Chalk streams must be appreciated. Because one of the manifestations of groundwater flooding is the increase in flowing length of the stream system, this must be characterised. In the Pang and Lambourn catchments, there are extensive data sets for stream gauging both from the LOCAR projects (Griffiths et al., 2006) and other previous work (Bradford, 2002; Grapes et al., 2005), which demonstrate the high baseflow of the rivers. Data for the River Lambourn show that flow accretes continuously, but nonuniformly, along its length, and that dry valleys are important in contributing groundwater flows to the river, appearing as step changes in the flow accretion curve. Data for the River Pang indicate that the middle section loses water to the Chalk, and that there are seasonal variations in behaviour, with significant baseflow in the summer being provided by the Blue Pool, which is the largest of a number of springs in the catchments. Other springs are associated with some of the smaller streams and rivers. A conceptual model of the catchment behaviour is provided by Wheater et al. (2007).

\section{The groundwater flood events of $2000 / 2001$ and $2002 / 2003$}

\section{Introduction}

The most significant recent groundwater flooding event occurred during the winter of 2000/2001 (see Figure 3). This event, typical of other Chalk catchments in south-east England, closed roads and flooded cellars for a number of weeks and months. The results of the flooding were recorded by a walk-over survey by the Environment Agency (Robinson et al., 2001) and by an aerial survey in the River Pang catchment (Finch et al., 2004). These data are 'snap-shots' of the flooding that occurred and do not give the duration of flooding. A less severe event occurred in the winter of 2002/ 2003. There are fewer data for the spatial extent of the 2002/ 2003 flooding (e.g. Environment Agency, 2003). While it is obvious that both events had a significant impact, a detailed hydrological and hydrogeological study has not been undertaken of both events. A brief summary of selected data sets are provided in the following sections to illustrate current understanding.

\section{Meteorological conditions}

The widespread flooding that occurred in 2000/2001 was, at the time, the most severe in the region since 1947 (Marsh and Dale, 2002). Total rainfall in England and Wales over the period September 2000 to April 2001 was 166\% of the longterm average (Marsh and Dale, 2002), and, based on 
(a)

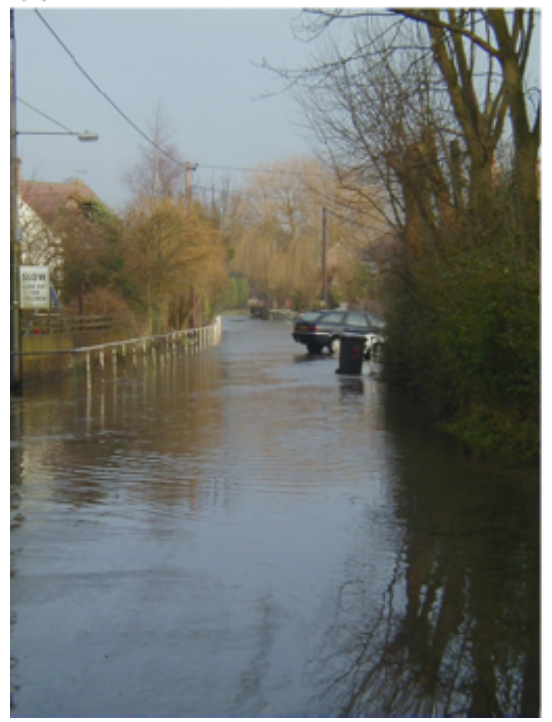

(b)

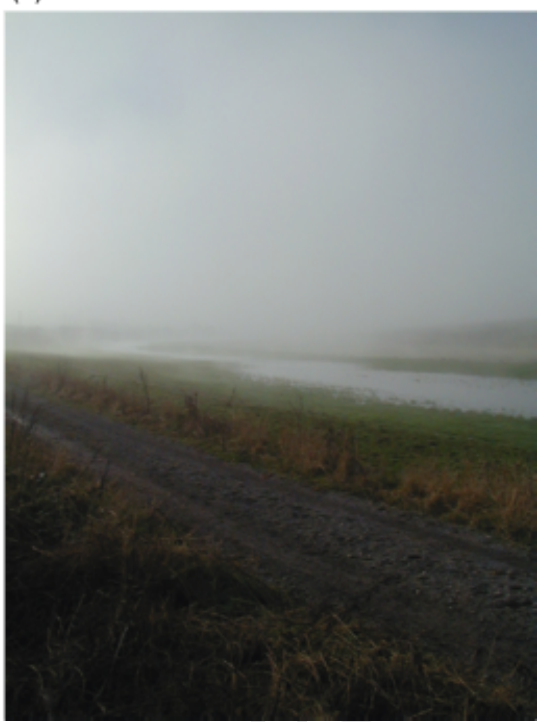

Figure 3 Photographs illustrating the extent of the 2000/2001 floods.

Environment Agency data, it is estimated that in the Thames region (south-east England) the period October 2000 to April 2001 received the highest 7-month rainfall total since 1885 (Morris et al., 2007). However, rainfalls within this period over shorter time scales (daily to monthly) were unexceptional. Defra (2001) found that 1-day rainfall extremes during this period were 'not the type of rainfall extremes' that caused the flooding. 'Flood-producing' rainfall had longer durations, and they reported that the 90-day total rainfall during October-December 2000 was the most extreme on record in England and Wales. Similar findings were reported for the Somme catchment in north-east France by Pinault et al. (2005), who attributed the unprecedented groundwater flooding in 2000/2001 to the accumulated wetness over 2 years, explained by the long-term rainfall behaviour.

The two most recent groundwater floods in the Pang catchment, are the most severe (2000/2001) and second most severe (2002/2003) in a record dating back to 1962. A 45-year record (1962-2007) of daily rainfall data from a rain gauge located at Wallingford, Berkshire (SU 617896, about $5 \mathrm{~km}$ to the north of the Pang catchment) was used to investigate meterological conditions on groundwater flooding. This was the nearest raingauge which provided a long-enough record for this analysis. Effective rainfall (ER) was calculated as rainfall minus evapo-transpiration (i.e. ignoring run-off and interception). Run-off is a very small proportion of rainfall in Chalk catchments and is ignored for the purposes of investigating groundwater flow. Daily evapo-transpiration was estimated from monthly MORECs actual evaporation data (Hough and Jones, 1997), for the MORECs grid cell 159, using linear interpolation in time. By simply examining the time series of daily ER (Figure 4) it is apparent that there are no exceptional daily ER totals associated with either flood event (consistent with DEFRA, 2001). To consider the impact of longer duration rainfall totals, time series of $n$ day accumulated ER totals can be plotted [where total ER on day $x$ is the sum of ER on days $x-(n-1)$ to $x$ ]. In addition, the $n$ day maximum event during each flood is ranked from the entire 45 year data set (Figure 4).

For durations of 2 months or less, both rainfall totals (not plotted) and ER totals (Figure 4) for each flood event were not the largest on record, in general becoming less extreme as the duration is reduced. For the 100 day (approx. 3 month) total, the 2002/2003 event was the most extreme event on record, though the 2000/2001 event was very similar, and both were significantly larger than the next largest total. For durations greater than 100 days, the 2000/ 2001 event was the most extreme, becoming much larger than the 2002/2003 event at longer durations (e.g. yearly).

These results suggest that the catchment has a time scale of about 3 months where around $100 \mathrm{~mm}$ of ER per month (i.e. $300 \mathrm{~mm}$ in total) is needed to bring the water table up to elevations sufficient to initiate groundwater flooding. Further, high levels of effective rain after this 'wet up' period then contribute to the length and severity of the flooding. Hence in 2002/2003, the water levels receded fairly rapidly (after about 2 months, Figure 4), while in 2000/2001 where high ER continued after the initiation of flooding, high water levels and associated flooding were maintained for about 8 months. 

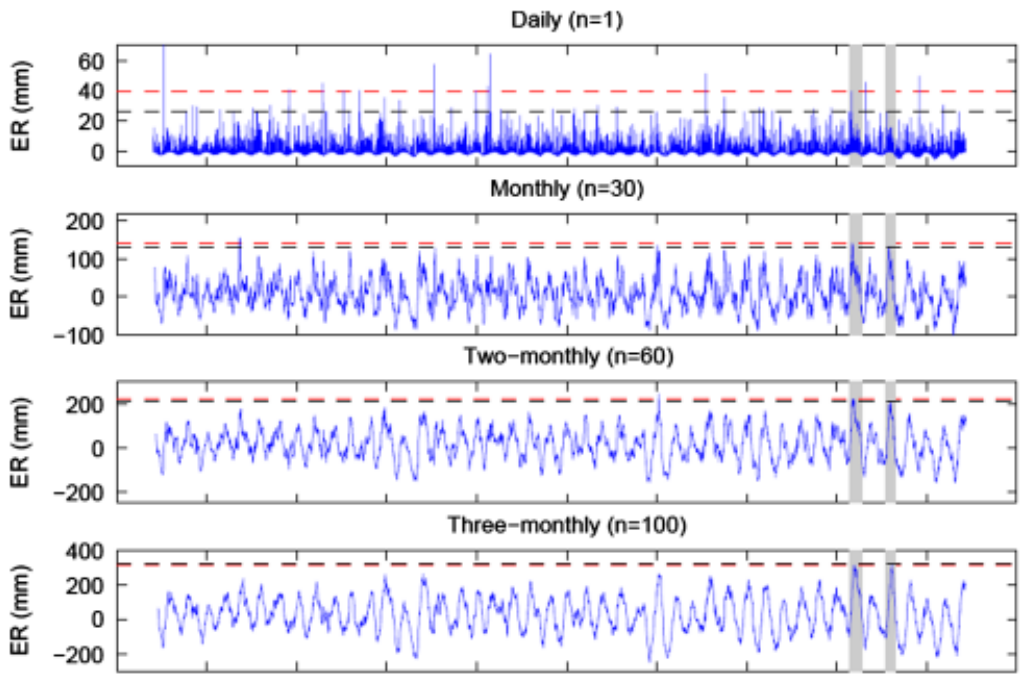

Yearly $(n=365)$

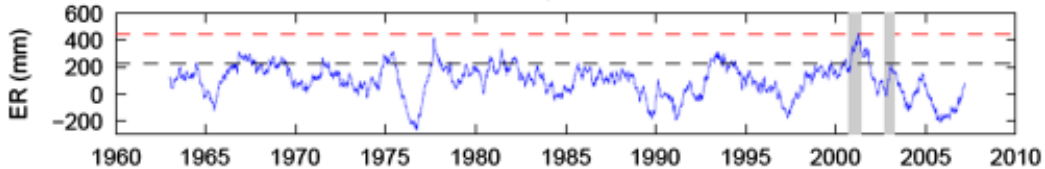

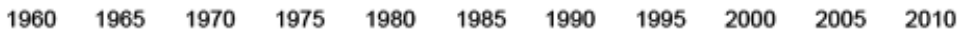

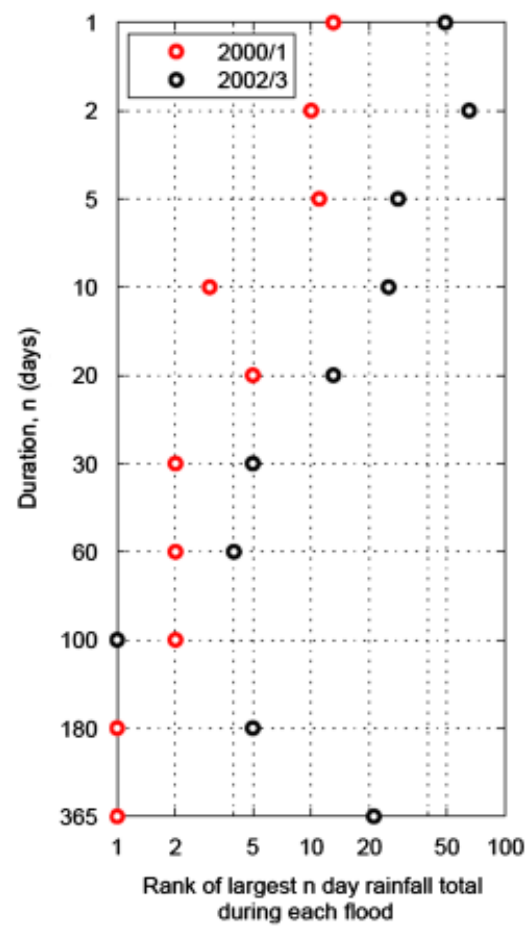

Figure 4 Flood producing effective rainfall in the Pang catchment.

\section{Duration of spring response}

In order to form a complete picture of the flooding related to the 2000/2001 and 2002/2003 flooding events, a questionnaire was sent to farmers within the River Pang and Lambourn catchments. In all, 300 questionnaires were sent out, which consisted of one page with tick box answers and a map of the area including their farm. The farmers were selected with the help of the National Farmers Union and the questionnaire was sent to $75 \%$ of the farmers in the area. The questionnaire focussed on identifying the extent and duration of the flood events by requesting the respondents to sketch the flooding that occurred on their property on the map provided. A total of 300 questionnaires were sent out and over 90 replies were received. From these responses, follow-up visits were arranged to enable a representative sample of farmers who had farms within the River Pang and Lambourn catchments to be interviewed. Fifteen visits were arranged with farmers whose land covered a range of slope (scarp, dip) as well as a range of Chalk and Palaeogenecovered areas.

The survey identified the importance of springs in contributing to groundwater flooding, especially in the upper part of the catchments. Spring systems were identified in the upper Lambourn, Pang and also in the Aldbourne, which is a tributary of the River Kennet. These springs flow in wet winters, typically between February and March or February to May (see Figure 5). For the winters of 2000/2001 and
2002/2003 the springflow started earlier (i.e. December) and continued flowing for longer (in the upper Pang until the following December).

\section{Groundwater level response}

Comparison of the groundwater hydrographs in the Pang and Lambourn catchments helps understand the response to recharge. A number of hydrographs have been produced for both catchments plotted for the water year 2000/2001 and 2002/2003 (i.e. 1 October to 30 September). To enable a suitable comparison with normal conditions, groundwater hydrographs for the year 1979/1980 (total annual ER this year was ranked 20 th from 45 years of data) have been selected as typical. Figure 6 shows the 2000/2001 recession continuing until mid-October, followed by a sharp rise then the groundwater levels stabilising, albeit exhibiting three peaks. These peaks are thought to correspond to recharge events. Once the recharge season is over, the groundwater levels begin to fall (recession) in mid-April 2001. The 2002/ 2003 hydrographs shows a rise slightly later (around midNovember) peaking at a lower level, but importantly the recession starts much earlier in mid-January. The rise in the groundwater hydrographs for the average year (1979/1980) starts in mid-January and peaks at the end of April. As would be expected, the peaks of the hydrograph during 1979/1980 are much lower than for the maximum 


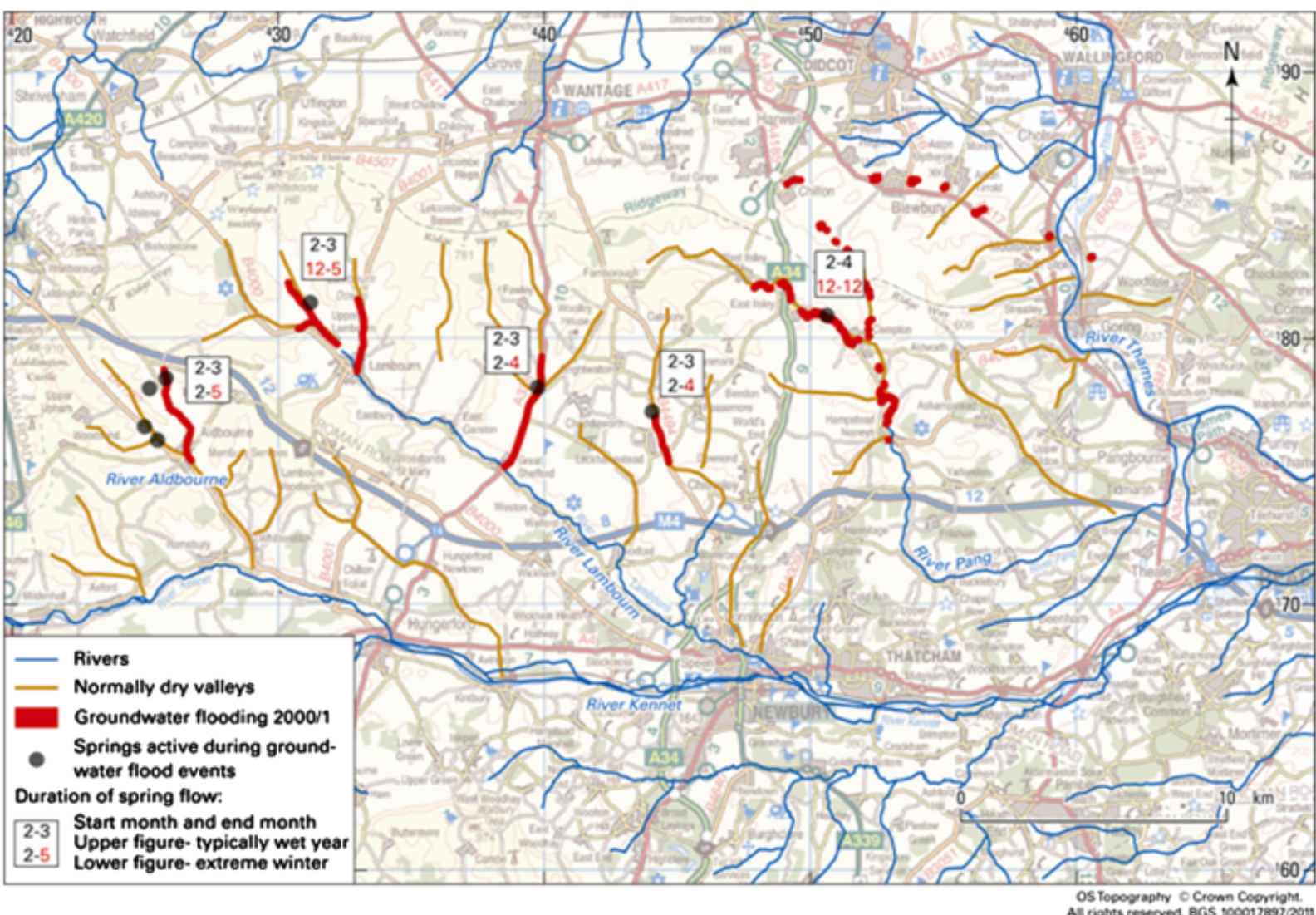

Figure 5 Extent of flooding combined with farmers' survey results.

groundwater levels during the flood events (2000/2001 and 2002/2003).

One of the more interesting aspects of comparing the $2000 / 2001$ hydrographs with $1979 / 1980$ is that groundwater levels are very similar at the start of the water year for the hydrographs in the River Lambourn catchment. For the Compton borehole, where extensive flooding occurred in the Pang catchment, the antecedent water levels before flooding were significantly higher than average, as reported by Finch et al. (2004). However, given that flooding also occurred in areas with unexceptional antecedent water levels (i.e. Malthouse and the Lambourn catchment boreholes), it seems more likely that the timing and volume of recharge were a more important control on flooding than the antecedent water levels. Marsh and Dale (2002) show the soil moisture deficit was very low at the end summer 2000 and state that the recharge season started 6-8 weeks earlier and continued for up to 24 weeks, which is consistent with the responses in Figure 6.

\section{Groundwater contours}

Figure 7 shows the groundwater contours for August 2000, November 2000, January 2001 and May 2001. These contours show the development of two groundwater mounds: the first, identified by the $140 \mathrm{~m}$ contour, develops in the upper part of the Lambourn catchment, the second is characterised by the $120 \mathrm{~m}$ contour. From August 2000 to November 2000 both contours move westwards as groundwater levels recede. From November 2000 to January 2001 both sets of contours move eastwards and form two mounds at the upper part of the River Lambourn and Pang catchments. These mounds persist until May 2001.

Examining the position of the 120 and $140 \mathrm{~m}$ contours shows the relationship of the groundwater contours with respect to the flooded dry valleys. The $140 \mathrm{~m}$ contour intercepts the dry valley of the Aldbourne and the upper part of the River Lambourn. The $120 \mathrm{~m}$ contour intercepts the flooded dry valleys along the River Lambourn, the Winterbourne and the upper part of the River Pang. There appears to be a crescent-shaped 'front' in both the River Pang and Lambourn catchments that intercepts the topographic lows and results in groundwater flooding.

Figure 8 shows the groundwater contours for November 2002, December 2002, April 2003 and May 2003. The contours remain static until November 2002, before moving eastwards and a groundwater mound develops in the upper part of the Pang and Lambourn. These mounds persist until 

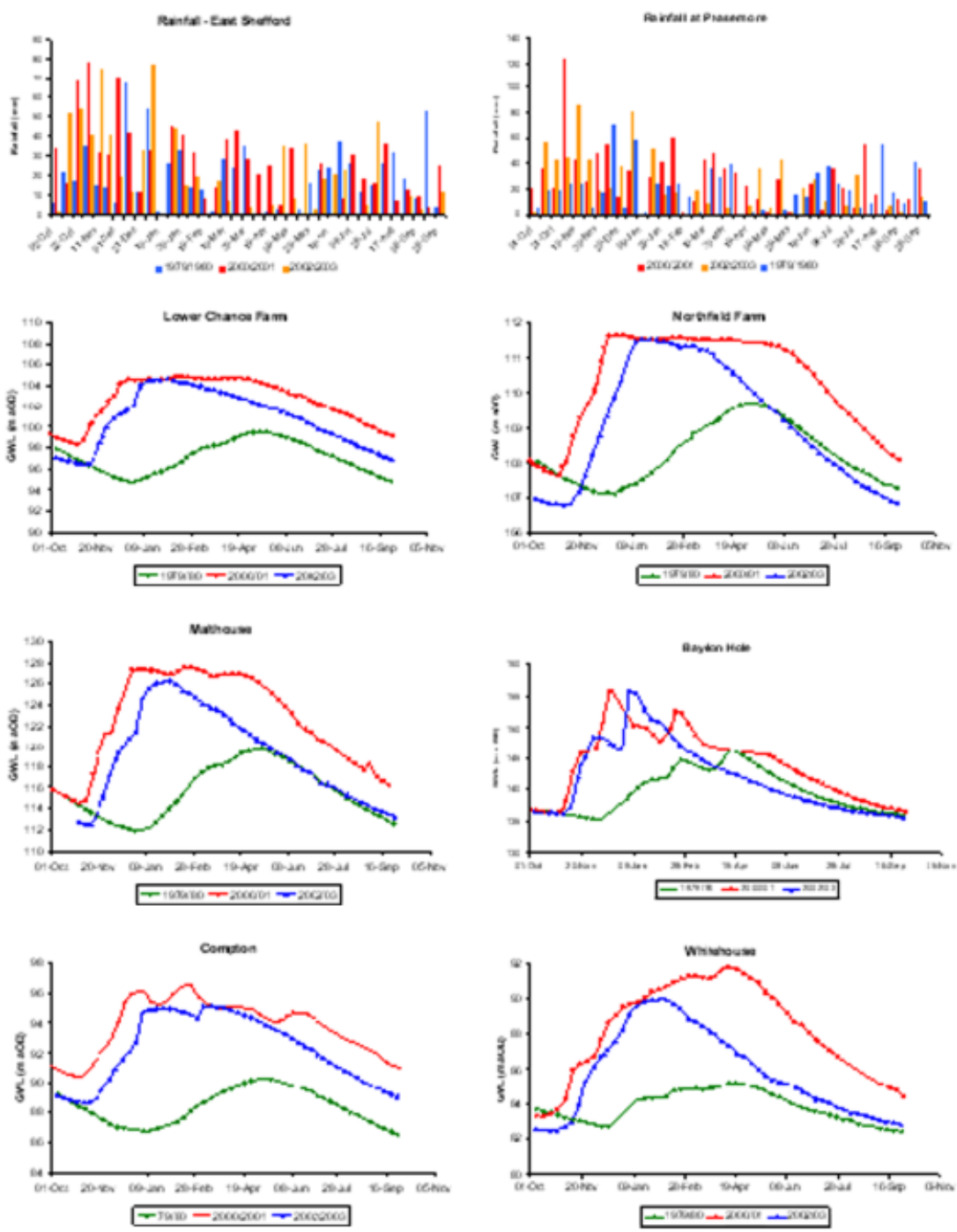

Figure 6 Rainfall combined with groundwater hydrographs.

April 2003, which is earlier in the year than in the 2000/2001 groundwater contours.

\section{Discussion}

Groundwater flooding poses a problem for flood risk assessment using traditional methods, due to the complex spatio-temporal nature of flooding and the mechanisms by which flooding is caused. A case study of historical Chalk groundwater flooding in the Pang and Lambourn catchments was used to illustrate response. In the upper parts of the catchments, normally dry valleys flow as groundwater levels rise, exhibiting intermittent (bourne) behaviour. This is the main cause of groundwater flooding. However, as well as dry valleys flowing in the upper parts of the catchments, groundwater flooding can result from existing

springs flowing either more frequently or for a longer period, or the emergence of 'new' spring sources, i.e. springs that may flow only during rare flood events. Both of these mechanisms have to be taken into account if the potential extent of flooding is to be mapped.

\section{Improving the assessment of flood risk}

As discussed above, the main issues regarding the successful understanding, simulation and forecasting of groundwater flooding are threefold: availability of data to define the spatial extent and timing of groundwater flooding, availability of suitable risk assessment tools and methods of forecasting the spatial extent of groundwater flooding. There is a significant issue concerning data availability because groundwater flooding usually occurs outside the 

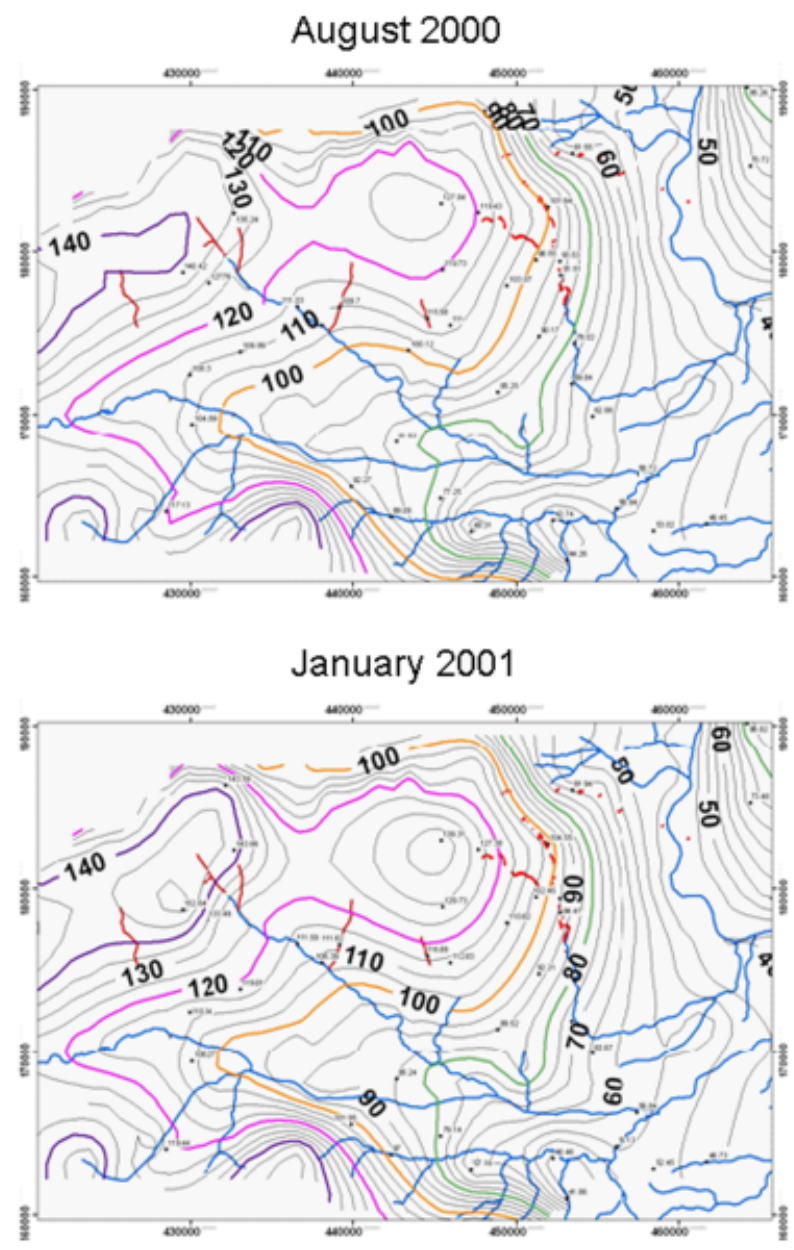

Figure 7 Groundwater contours for 2000/2001.

area normally covered by the installed hydrometric networks, for example, in the Chalk, in normally dry valleys. The methods by which data collection can be facilitated include aerial surveys (e.g. Finch et al., 2004), field surveys including photography, and temporary flow measurement (e.g. Macdonald et al., 2007). All these measures depend on rapid response and require the development of contingency plans as well as the accessibility of the flooded areas by foot or vehicles. This is a significant issue where roads are blocked by flood waters.

In order to better assess flood risk, groundwater flooding processes need to be simulated in flood-risk models. Thus it is necessary to include appropriate groundwater modelling in flood risk assessment methodologies. Achieving this aim presents considerable challenges in both process understanding and modelling methodologies. In addition to the need for a suitably fine temporal and spatial representation of the processes, a set of methodological problems occur which cannot be solved using proprietary groundwater models. Firstly, simulation of groundwater emergence
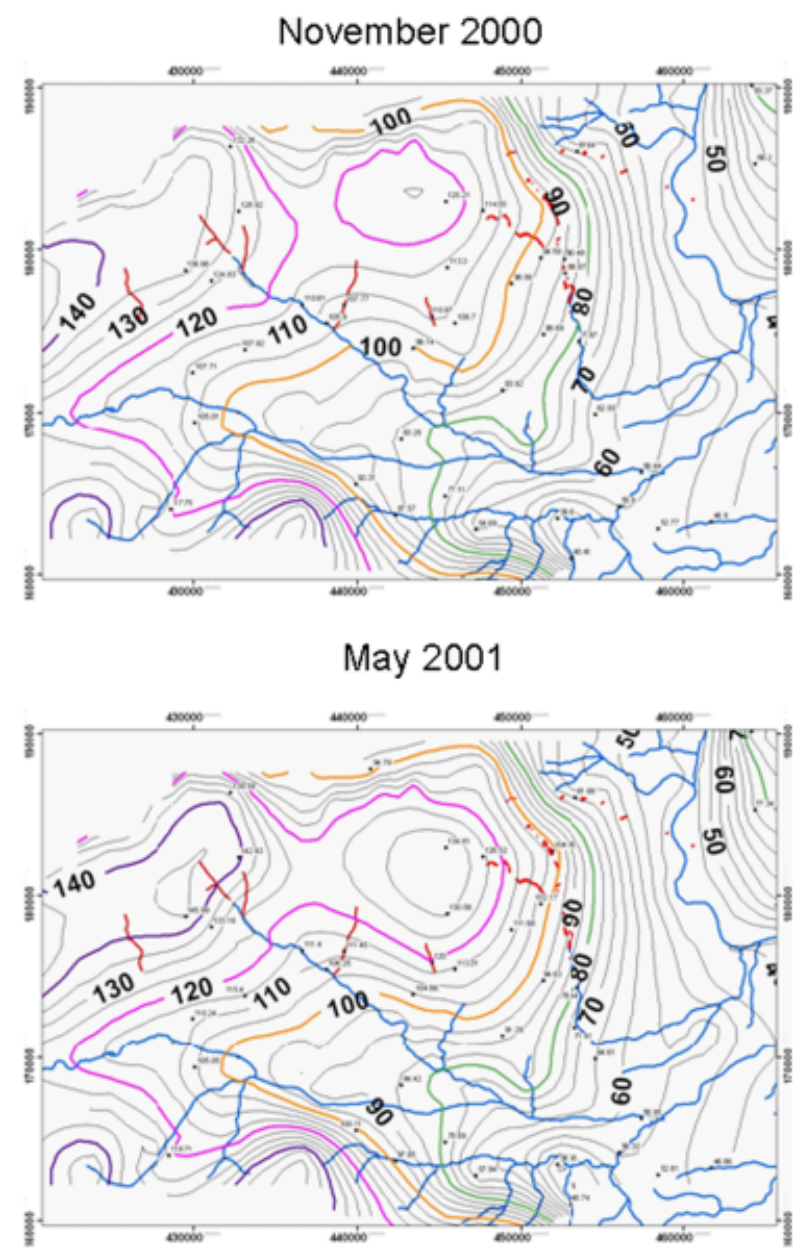

requires accurate representation of surface elevations within the groundwater model, a feature which is generally not included in proprietary groundwater models. This requires high vertical resolution data, and raises issues of grid-scale representation. Secondly, the emergence of groundwater occurs in normally dry valleys in a low run-off environment, and to a lesser extent from springs in the upper part of the catchment. This extends the drainage network considerably by processes that are not normally simulated. Therefore, consideration has to be given to potential flow paths in model definition and set-up. Thirdly, recharge processes are spatially variable, exhibit high nonlinearity of response, and are not represented appropriately in standard models. Fourthly, stream-aquifer interactions are spatially complex. Current algorithms are simplistic, and detailed definition requires extensive field investigation. Ongoing research under the UK Flood Risk from Extreme Events (FREE) programme is addressing these challenges, but a comprehensive risk assessment tool remains a challenge for the future. 

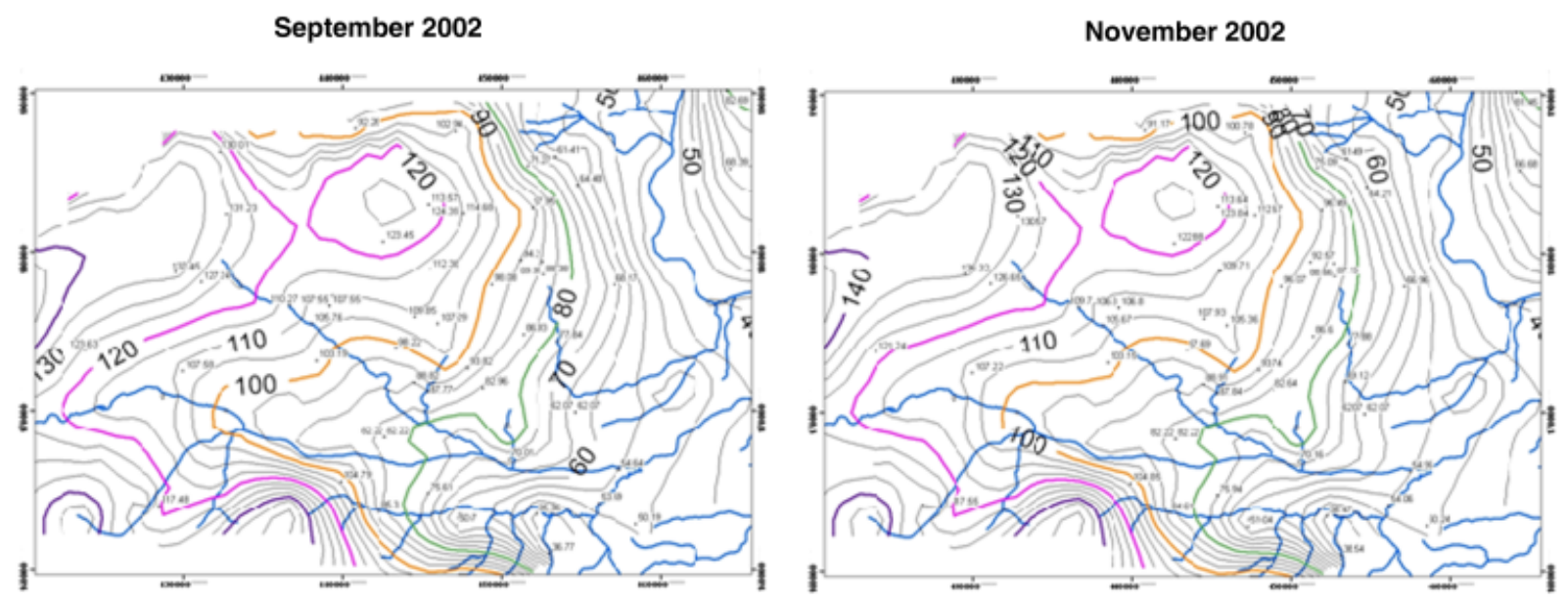

January 2003
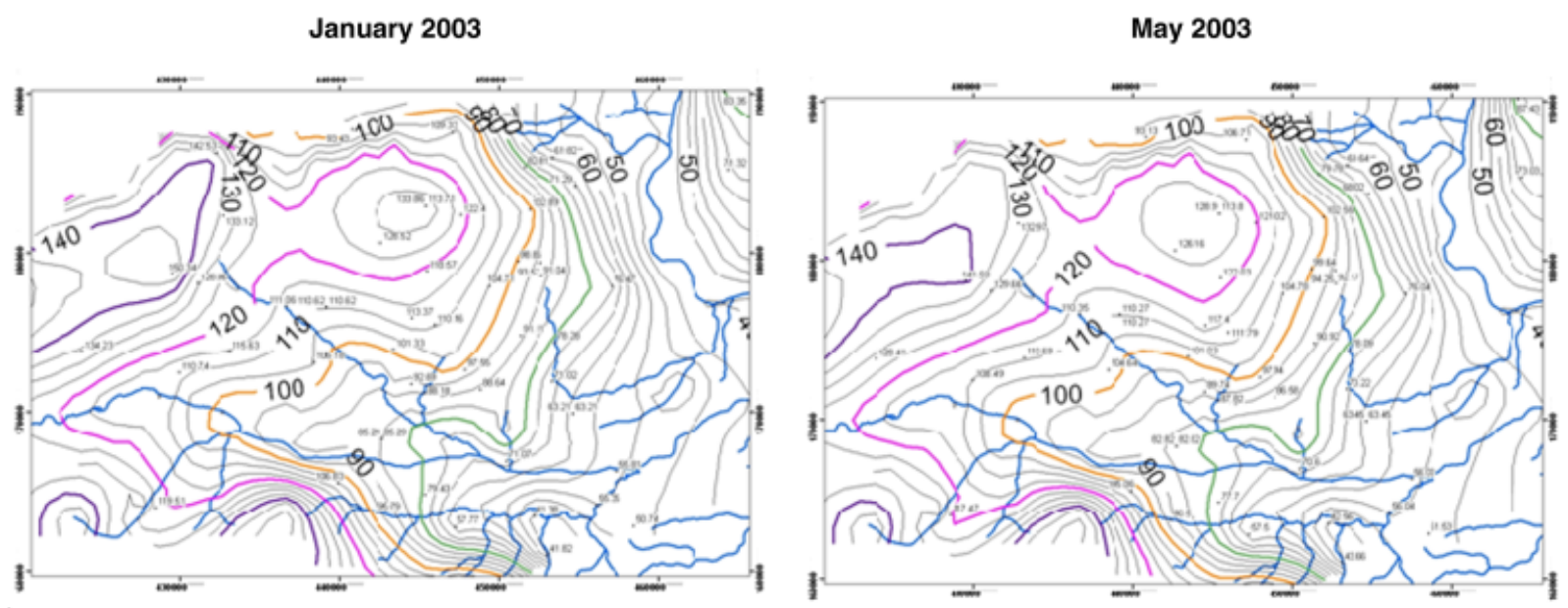

Figure 8 Groundwater contours for 2002/2003.

Forecasting of groundwater flooding is also important, especially under conditions of climate change. Although in principle, complex distributed groundwater models could be used for forecasting, simpler modelling approaches can provide a cheap and effective flood warning system. Such models benefit from computational efficiency and ease of setup and use. Because groundwater flooding occurs after a combination of antecedent conditions for soil moisture deficit and early and sustained winter rainfall, early warning can be provided if there is an understanding of the current groundwater conditions in combination with a range of possible rainfall scenarios. The UK's Environment Agency uses such an approach to forecast when groundwater levels may exceed some 'trigger' level, associated with past flooding. An example for the Brighton area has been developed by Adams et al. (2010). Such methods could potentially be improved by looking at ER, rather than just rainfall, and by considering a range of 'flood producing' durations. These point methods can provide a good indication of the likelihood of groundwater flooding, but do not indicate where the flooding will take place, and also have limited application in areas where little is known about historic flood events.

To develop these simple, point methods further Fulton (2009) and Fulton and Jackson (2010) have proposed a method for predicting the groundwater surface over the whole catchment. A number of point models are used to simulate individual groundwater hydrographs. Using methods to characterise all of the groundwater hydrographs in the Pang and Lambourn catchments, the number of simple models required can be reduced by an order of magnitude. Using spatial interpolation, the groundwater surface can be estimated for any time. This groundwater surface can be compared with the ground surface and groundwater flood maps can be created. This approach appears promising as a rapidly deployable risk assessment tool. However, it requires sufficient numbers of well-placed observation boreholes within the catchment to characterise the flooding. Moreover, like other simple modelling approaches, it is limited to predictions within the range of historic observations. 
Despite the advances in understanding groundwater flooding in the Pang and Lambourn catchments reported in this paper, there remain three challenges to the understanding and simulation of groundwater flooding: data availability, incorporation of the simulation of groundwater flows into a flood risk framework and the forecasting of groundwater flooding. While research programmes such as the NERC-funded FREE programme are helping to address these issues (Rees et al., 2009; Wheater et al., 2010), there remains much work to do in terms of ensuring that groundwater flooding is routinely incorporated into flood risk assessments.

\section{Acknowledgements}

This work was undertaken as part of the 'Modelling groundwater flood risk in the Chalk aquifer from future extreme rainfall events' project funded by NERC (Grant NE/ E002307/1). Two anonymous reviews are gratefully acknowledged as well as internal BGS review by Dr Nick Robins. This paper is published with the permission of the Executive Director of the British Geological Survey (NERC).

\section{References}

Adams B., Bloomfield J., Gallagher A., Jackson C., Rutter H. \& Williams A. FLOOD 1 Final Report. BGS Groundwater Management Programme Internal Report IR/06/033, 2008.

Adams B., Bloomfield J., Gallagher A., Jackson C., Rutter H. \& Williams A. An early warning system for groundwater flooding in the Chalk. Q J Eng Geol Hydrogeol 2010, 43, (2), 185-193.

Allen D.J., Brewerton L.J., Coleby L.M., Gibbs B.R., Lewis M.A., Macdonald A.M., Wagstaff S.J. \& Williams A.T. The physical properties of major aquifers in England and Wales. British Geological Survey Report WD/97/34 - Environment Agency R\&D Publication 8, 1997.

Banks D., Davies C. \& Davies W. The Chalk as a karstic aquifer evidence from a tracer test at Stanford-Dingley, Berkshire, UK. Q J Eng Geol 1995, 28, S31-S38.

Binnie Black and Veatch. Flood defence assessment of downland flooding. Report for Brighton and Hove Council, 2001.

Bradford R.B. Controls on the discharge of Chalk streams of the Berkshire Downs, UK. Sci Total Environ 2002, 282, 65-80.

Cobby D., Morris S., Parkes A. \& Robinson V. Groundwater flood risk management: advances towards meeting the requirements of the EU floods directive. J Flood Risk Manage 2009, 2, (2), 111-119.

Defra. To what degree can the October/November 2000 flood events be attributed to climate change? Defra Technical Report FD2304, 2001.

Defra. Making space for water: developing a new Government strategy for flood and coastal erosion risk management: a consultation exercise. London: Defra, 2004.
Environment Agency. West Berkshire Groundwater Scheme Pump Operations Report 2002/2003. Unpublished Report, 5pp, 2003.

Environment Agency. Flooding in England: a National Assessment of Flood Risk. 36pp, 2009.

Finch J.W., Bradford R.B. \& Hudson J.A. The spatial distribution of Groundwater flooding in a chalk catchment in southern England. Hydrolog Processes 2004, 18, 959-971.

Fulton K.A. Prediction of groundwater flooding in Chalk catchments using statistical methods for hydrograph classification and a lumped parameter groundwater model. MSc Thesis, Cardiff, 2009.

Fulton K.A. \& Jackson C.R. Simulation of the spatio-temporal extent of groundwater flooding using statistical methods of hydrograph classification and lumped parameter models. Hydrolog Processes (submitted).

Grapes T.R., Bradley C. \& Petts G.E. Dynamics of river-aquifer interactions along a chalk stream: the River Lambourn, UK. Hydrolog Processes 2005, 19, 2035-2053.

Griffiths J., Binley A., Crook N., Nutter J., Young A. \& Fletcher S. Streamflow generation in the Pang and Lambourn catchments, Berkshire, UK. J Hydrol 2006, in press.

Habets F., Gascoin S., Korkmaz S., Thiéry D., Zribi M., Amraoui N., Carli M., Ducharne A., Leblois E., Ledoux E., Martin E., Noilhan J., Ottlé C. \& Viennot P. Multi-model comparison of a major flood in the groundwater-fed basin of the Somme River (France). Hydrol Earth Syst Sci 2010, 14, 99-117.

Hough M.N. \& Jones R.J.A. The United Kingdom Meteorological Office rainfall and evaporation calculation system: MORECS version 2.0 - an overview. Hydrol Earth Syst Sci 1997, 1, 227-239.

Ireson A.I., Butler A.B. \& Wheater H.S. Evidence for preferential fracture flow in the Chalk unsaturated zone. Proc Br Hydrolog Soc Symp 2010 (submitted).

Ireson A.M., Butler A.P. \& Gallagher A. Groundwater flooding in fractured permeable aquifers. IAHS Hyderabad JS.3 volume: improving integrated surface and groundwater resource management in a vulnerable and changing world, 2009a.

Ireson A.M., Mathias S.A., Wheater H.S., Butler A.P. \& Finch J. A model for flow in the Chalk unsaturated zone incorporating progressive weathering. J Hydrol 2009b, 365, 244-260 . Available at http://dx.doi.org/10.1016/j.jhydrol.2008.11.043.

Jackson I., ed. Britain Beneath Our Feet. An Atlas of Digital Information on Britain's Land Quality, Underground Hazards, Resources and Geology. ISBN 085272479. British Geological Survey, 2004.

Jacobs Strategy for flood and erosion risk management: groundwater flooding scoping study (LDS 23). Reading: Jacobs, 2004.

Jacobs. Making space for water - Groundwater flooding records collation, monitoring and risk assessment. Extended Report (Chalk Aquifer). Technical Report HA5. Environment Agency, 2006.

Johnston P. \& Peach D.W. Groundwater modelling in the Karst Limestones of the Gort Lowlands. In: Proceedings of the 
Portlaoise Seminar, April 1998. International Association of Hydrogeologists, 1998.

Korkmaz S., Ledoux E. \& Onder H. Application of the coupled model to the Somme river basin. J Hydrol 2009, 366, (1-4), 21-34.

Lees M.J., Price N., Wheater H.S. \& Peach D. A rainfall-runoff simulation model for South Galway, Ireland. Hydrol Changing Environment 1998, III, 93-104.

MacDonald A.M., Brewerton L.J. \& Allen D.J. Evidence for rapid groundwater flow and karst-type behaviour in the Chalk of southern England. Groundwater pollution, aquifer recharge and vulnerability, Vol. 130. London: Geological Society, Special Publications, 1998, 95-106.

MacDonald A.M., Hughes A.G., Vounaki T., Graham M.T., Lilly A., Mansour M. \& Stephens C.A. Groundwater and the Forres (River Findhorn \& Pilmuir) flood alleviation schemes. British Geological Survey Commissioned Report CR/08/023, 2008b.

Macdonald D.M.J., Bloomfield J.P., Hughes A.G., MacDonald A.M., Adams B. \& McKenzie A.A. Improving the understanding of the risk from groundwater flooding in the UK. Proceedings of FLOOD risk 2008, European Conference on Flood Risk Management, Oxford, UK, 30 September to 2 October 2008.

Macdonald D.M.J., Hall R., Carden D., Dixon A., Cheetham M., Cornick S. \& Clegg M. Investigating the inter-dependencies between surface and groundwater in the Oxford area to help predict the timing and location of ground-water flooding and to optimise flood mitigation measures. Proceedings of $42 \mathrm{nd}$ Defra Flood and Coastal Management Conference, 2007.

Marechal J.C., Ladouche B. \& Dorfliger N. Karst flash flooding in a Mediterranean karst, the example of Fontaine de Nîmes. Eng Geol 2008, 99, (3-4), 138-146.

Marsh T.J. \& Dale M. The UK Floods of 2000-2001: a hydrometeorological appraisal. J Chartered Inst Water Environ J 2002, 16, (3), 180-188.

Marsh T.J. \& Hannaford J. The summer 2007 floods in England and Wales - a hydrological appraisal. Centre for Ecology \& Hydrology, 2007. 32pp.

Maurice L.D., Atkinson T.C., Barker J.A., Bloomfield J.P., Farrant A.R. \& Williams A.T. Karstic behaviour of groundwater in the English Chalk. J Hydrol 2006, 330, 63-70.

McKenzie A.A., Bloomfield J.P., Hulbert A. \& Rutter H.K. Confidence and groundwater flood susceptibility mappingIn: Winstanley A.C., ed. GISRUK 2007 - Geographical Information Science Research UK Conference 2007, 11-13 April 2007, ISBN 090151986 3. County Kildare, Ireland: National Centre for Geocomputation, National University of Ireland Maynooth, 2007.

Q9 McMahon L. The story of compton: a Berkshire downland village. Compton Parish Council, 2000.

Morris S.E., Cobby D. \& Parkes A. Towards groundwater flood risk mapping. Q J Eng Geol Hydrogeol 2007, 40, 203-211.
Najib K., Jourde H. \& Pistre S. A methodology for extreme groundwater surge predetermination in carbonate aquifers: groundwater flood frequency analysis. J Hydrol 2008, 352, $1-15$.

Owen M. \& Robinson V.K. Characteristics and yield of fissured Chalk. In: Thames groundwater scheme. London: Institution of Civil Engineers, 1978.

Peach D.W., Shand P., Gooddy D.C., Abesser C., Bloomfield J.P. \& Gallagher A.J. Hydrogeology and hydrochemistry of the Pang and Lambourn catchments, Berkshire, UK. British Geological Survey Commissioned Report, CR/06/046N, 2006.

Peach D.W., Watson S.J., Carpenter C.R. \& Wheater H.S. An investigation of the Flooding Problems in the Gort-Ardrahan area of South Galway, Ireland Interim and final reports to Public Works Dept, Government of Ireland, interim and final report, 19 volumes, 1997.

Pinault J.L., Amraoui N. \& Golaz C. Groundwater-induced flooding in macropore-dominated hydrological system in the context of climate changes. Water Resources Res 2005, 41, (5).

Pitt M. Learning lessons from the 2007 floods. Cabinet Office, 2008.

Rees J.G., Gibson A.D., Hughes A. \& Walsby J. Regional modelling of geohazard change. Geological Society of London Engineering, Geology Special Publication 23, 2009.

Robinson V.K. The hydrogeological model of the Kennet Chalk aquifer. Reading: Thames Conservancy Division, Thames Water Authority, 1976.

Robinson V., Solomon J. \& Morris S. Groundwater flooding in the Thames region, winter 2000/2001. Environment Agency, 2001.

Taylor S.M., The Chichester Flood, January 1994. CEH.

USGS. USGS Fact Sheet 111-00, Ground-water flooding in Glacial Terrain. Pierce County, Washington: USGS, 2000.

Vekerdy Z. \& Meijerink A.M.J. Statistical and analytical study of the propagation of flood-induced groundwater rise in an alluvial aquifer. J Hydrol 1998, 205, (1-2), 112-125.

Visocky A.P. Determination of 100-year ground-water flood danger zones of the Havanna and Bath areas, Mason County, Illinois: Illinois State Water Survey, Contract Report 584, 15pp, 1995.

Wheater H.S., Ireson A.M., Butler A.P., Parker S., Peach D.W., Jackson C.R., Hughes A.G., Vounaki T. \& Finch J. Managing extremes in groundwater-dominated catchments: the Chalk of SE England. Proc Br Hydrol Soc Symp 2010 (submitted).

Wheater H.S., Neal C. \& Peach D. Hydro-ecological functioning of the Pang and Lambourn catchments, UK: an introduction to the special issue. J Hydrol 2006, 330, 1-9.

Wheater H.S., Peach D. \& Binley A. Hydrology and Earth system sciences. Characterising groundwater-dominated lowland catchments: the UK Lowland Catchment Research programme (LOCAR). Hydrol Earth Syst Sci 2007, 11, 108-124. 


\section{Author Query Form}

\begin{tabular}{ll}
\hline Journal & JFRM \\
Article & 1095
\end{tabular}

Dear Author,

During the copy-editing of your paper, the following queries arose. Please respond to these by marking up your proofs with the necessary changes/additions. Please write your answers clearly on the query sheet if there is insufficient space on the page proofs. If returning the proof by fax do not write too close to the paper's edge. Please remember that illegible mark-ups may delay publication.

\begin{tabular}{|c|c|c|}
\hline Query No. & Description & Author Response \\
\hline Q1 & $\begin{array}{l}\text { AUTHOR: A running head short title was not supplied; please check if this one is suitable and, if not, please supply a } \\
\text { short title that can be used instead. }\end{array}$ & \\
\hline Q2 & AUTHOR: Please supply a maximum of 8 keywords. & \\
\hline Q3 & $\begin{array}{l}\text { AUTHOR: Papers that have not yet been accepted for publication should not be included in the Reference List; } \\
\text { they should be cited in the text as 'Fulton and Jackson, unpublished data'. Please update Reference Fulton and } \\
\text { Jackson (submitted) if it has now been published, use 'in press' (with journal title details, if appropriate) if it has been } \\
\text { accepted for publication, or remove it from Reference List and change to 'Fulton and Jackson, unpublished data' in } \\
\text { the text if it has not yet been accepted. }\end{array}$ & \\
\hline Q4 & AUTHOR: Please provide volume and page-range for reference Griffiths (2006). & \\
\hline Q5 & AUTHOR: Please provide volume and page-range for reference Ireson et al. (2010). & \\
\hline Q6 & AUTHOR: Please provide location of publisher for reference Jackson (2004). & \\
\hline Q7 & AUTHOR: Please provide location of publisher and page-range for reference Johnston and Peach (1998). & \\
\hline Q8 & AUTHOR: Please provide location of publisher for reference Marsh and Hannaford (2007). & \\
\hline Q9 & AUTHOR: Please provide location of publisher for reference McMahon (2000). & \\
\hline Q10 & AUTHOR: Please provide page-range for reference Owen and Robinson (1978). & \\
\hline Q11 & $\begin{array}{l}\text { AUTHOR: Peach et al., } 2006 \text { has not been cited in the text. Please indicate where it should be cited; or delete from } \\
\text { the Reference List. }\end{array}$ & \\
\hline Q12 & AUTHOR: Please provide page-range for reference Pinault et al (2005). & \\
\hline Q13 & AUTHOR: Please provide location of publisher for reference Rees et al (2009). & \\
\hline Q14 & AUTHOR: Please provide location of publisher for reference Robinson et al (2001). & \\
\hline Q15 & AUTHOR: Please provide volume and page-range for reference Wheter et al. (2010). & \\
\hline
\end{tabular}




\title{
Author Query Form
}

\author{
Journal JFRM \\ Article 1095
}

\section{Dear Author,}

During the copy-editing of your paper, the following queries arose. Please respond to these by marking up your proofs with the necessary changes/additions. Please write your answers clearly on the query sheet if there is insufficient space on the page proofs. If returning the proof by fax do not write too close to the paper's edge. Please remember that illegible mark-ups may delay publication.

\begin{tabular}{|c|l|c|}
\hline $\begin{array}{c}\text { Query } \\
\text { No. }\end{array}$ & \multicolumn{1}{|c|}{ Description } & Author Response \\
\hline \hline Q16 & $\begin{array}{l}\text { AUTHOR: Figures } 1,2,4,5,6,7 \text { and } 8 \text { are of poor quality. Please check required artwork } \\
\text { specifications at http:// authorservices.wiley.com/ bauthor/illustration.asp }\end{array}$ & \\
\hline & & \\
\hline & & \\
\hline & & \\
\hline & & \\
\hline & & \\
\hline & & \\
\hline
\end{tabular}

